\title{
Identification of Formaldehyde Bananas Using Learning Vector Quantization
}

\author{
R Musa ${ }^{1}$, M Akbar ${ }^{2}$ \\ ${ }^{1,2}$ Study Program of Informatics, Faculty of Information Technology, \\ University of Mercu Buana Yogyakarta
}

E-mail: kaangmamat@gmail.com¹, mutaqin@mercubuana-yogya.ac.id ${ }^{2}$

Submitted:14 January 2021, revised: 25 February 2021, accepted: 26 February 2021

\begin{abstract}
Abstrak. Pisang yang matang dengan proses kimiawi atau tidak matang secara alami biasanya, hal ini bisa dikenali dengan adanya bercak-bercak berwarna kehitaman pada permukaan kulitnya. Tetapi pengenalan secara visual memiliki kekurangan yaitu sulit dalam mengenali kemiripan antara pisang formalin dan pisang alami sehingga berdampak pada kurang akurat nya terhadap identifikasi tersebut. Pada penelitian ini, dibangun suatu sistem yang dapat menentukan buah pisang formalin maupun buah pisang alami melalui identifikasi citra digital menggunakan supervised classification. Citra yang akan diidentifikasi sebelumnya melewati proses transformasi warna RGB (Red Green Blue) ke Grayscale, dan proses ekstraksi fitur tekstur menggunakan fitur-fitur yang dapat dikenali secara statistis melalui histogram, berupa rerata, standar deviasi, skewness, kurtosis, energi, entropi dan smoothness. Hasil ekstraksi fitur tekstur diklasifikasi dengan LVQ (Learning Vector Quantization) untuk menentukan buah pisang formalin atau alami. Pengujian dilakukan dengan 122 data sampel citra buah pisang, 100 citra sebagai data latih yang terdiri dari 50 citra untuk pisang alami dan 50 citra untuk pisang formalin, 22 citra sebagai data uji. Hasil pengujian menunjukkan metode LVQ memiliki persentase terbaik pada learning rate 0.1 , penurunan learning rate 0.75 dan maksimal iterasi 1000 dengan iterasi terkecil yaitu 7, memperoleh hasil accuracy $90.90 \%$, precision $84.61 \%$ dan recall $100 \%$.
\end{abstract}

Kata kunci: Learning Vector Quantization; Jaringan Saraf Tiruan; pisang.

Abstract. Bananas ripened via chemical processes, or even unnaturally, can usually be recognized by the blackish spots on the peel surface. However, visual recognition has a drawback that makes it difficult to recognize the similarities between formaldehyde bananas and the natural ones, therefore it has an inaccurate impact on the identification. In this research, a system was built to determine formaldehyde and natural bananas by identifying digital images using supervised classification. The identified images previously went through the color transformation process from RGB (Red Green Blue) to grayscale, and the texture feature extraction process used the features that could be recognized statistically through a histogram, such as mean, standard deviation, skewness, kurtosis, energy, entropy, and smoothness. The results of texture feature extraction were classified by LVQ (Learning Vector Quantization) to determine the formaldehyde or natural bananas. The test was carried out with 122 sample data for banana images: 100 images as the training data, consisting of 50 images for the natural bananas, and 50 images for the formaldehyde bananas, and the other 22 images as the testing data. The test results showed that the LVQ method had the best percentage at the learning rate of 0.1 , the decrease in learning rate of 0.75 , and the maximum iteration of 1000 with the smallest iteration of 7, obtaining $90.90 \%$ accuracy, $84.61 \%$ precision, and $100 \%$ recall.

Keywords: Learning Vector Quantization; Artificial Neural Network; bananas. 


\section{Introduction}

Banana is the most popular fruit in Indonesia and often used as the main ingredient in processing food. Banana production has increased by an average of 7.5\% per year from 2004-2009 in North Sumatra, however in 2010 the banana production decreased by $9.7 \%$ from the previous year. This is due to the disturbance of organism that causes the banana production to decrease, such as fusarium wilt disease [1]. According to the Central Bureau of Statistics (2005) the regions that are central to banana plants in North Sumatra are Langkat, North Tapanuli, Simalungun, Dairi, Asahan, Serdang Bedagai, and Deli Serdang Regencies with respective production percentage of $27.90 \% ; 14.91 \% ; 12.28 \% ; 6.08 \% ; 5.81 \%$; 5.73 and $5.69 \%$ of the total banana production in North Sumatra [2].

Even though the banana plant production is increasing, there are still many people who take advantage of this opportunity by ripening banana with ingredients. Banana that is ripe with chemical processe has other effects, one of them is disrupting fertility. This is caused by the entry of carbide into the body and ultimately affects our reproductive system. Banana that is ripe by chemical process usually characterized by the presence of blackish spots on the skin surface. Even though the banana looks yellowish and ripe, this chemical banana does not have the distinctive aroma of ripe banana. It indicates that the ripening process of the fruit which is widely known to be good for digestive health is unnatural and may not be good for health. Natural process ripe banana contains vitamin B, C, protein and carbohydrates. Banana that is ripened to be more ripe has imperfect nutrients, in fact, in many cases the banana does not have any nutrients so it will not get any health benefits [3].

In choosing fruit by using the human senses, of course it has become ordinary and commonplace, but it does not rule out the possibility of errors in the fruit selection. For this reason, an intelligent system in fruit selection will be very useful and beneficial for customers. Many studies conducted by experts in the field of artificial intelligent only focus on the level of maturity of the fruit produced and only a few have conducted a study on chemical fruits, this happens that there is awareness in humans generally occurs in people in Indonesia because the level of health awareness is still lacking. Several previous studies to evaluate and classify the ripeness of banana using image processing [4]. Identification of fruit plants based on features of shape, color and leaf texture based on image processing and Learning Vector Quantization (LVQ), the study conducted by Sutarno, Rouzan Fiqri Abdullah and Rossi Passarella obtained test results with a success rate of $82 \%$ in recognizing fruit plants based on their leaves [5].

There are various algorithms for pattern recognition that can be applied to identify formaldehyde bananas using their peels. However, most of the recognition methods use the nearest neighbor-based method [6]. The neighbor-based method has the advantage of being simple and easy to implement. However, there is a drawback, namely it is slow if large amounts of data are used [7]. Alternative method that can be used to recognize patterns on banana peels is artificial neural networks. The performance comparison between the neighbor-based method and the artificial neural network shows that the neural network is able to identify formaldehyde banana better than the nearest neighbor [8].

Backpropagation Network and Learning Vector Quantization (LVQ) are the most commonly used neural network algorithms to solve pattern recognition problems. Backpropagation has the advantage of finding optimal results and on the other hand, LVQ classifies based on sample vectors from semioptimal training data [9]. In terms of performance, LVQ and Backpropagation have similar performances [10].

Based on the existing problems, this paper will identify formaldehyde banana using LVQ with the features used derived from the characteristics found in banana peels.

\section{Literature Review}

\subsection{Grayscale Image}

Grayscale image is an image whose pixel value represents the degree of gray on the white intensity. Each pixel value in grayscale image corresponds to its brightness. The pixel value of grayscale image will be represented by byte or word with 8-bit value, the intensity of the brightness varies from 0 to 
255 , " 0 " is represented as black and " 255 " is represented as white [11]. Following is the image conversion formula where $\mathrm{R}$ is the red channel, $\mathrm{G}$ is the green channel and $\mathrm{B}$ is the blue channel [12].

$$
\text { Grayscale }=((R * 0.2989)+(G * 0.5870)+(B * 0.1140))
$$

\subsection{Features Extraction}

A simple method for obtaining texture is to base on the histogram. An image with a subtle texture has a narrow area of change in intensity. In contrast, grainy image has high contrast, characterized by a wide range of intensities. Some of the formulas used in this study are as follows [13].

$$
\begin{gathered}
m=\sum_{i=0}^{L-1} i . p(i) \\
\sigma=\sqrt{\sum_{i=1}^{L-1}(i-m)^{2} p(i)} \\
\text { skewness }=\sum_{i=1}^{L-1}(i-m)^{3} p(i) \\
\text { kurtosis }=\sum_{i=1}^{L-1}(i-m)^{4} p(i)-3 \\
\text { energy }=\sum_{i=0}^{L-1}[p(i)]^{2} \\
\text { entropy }=-\sum_{i=0}^{L-1}(i) \log _{2}(p(i)) \\
R=1-\frac{1}{1+\sigma^{2}}
\end{gathered}
$$

Description:

$i=$ grayscale in the image $f$

$p(i)=$ probability of occurrence $i$

$\mathrm{L}=$ highest grayscale value

$\sigma=$ standard deviation

\subsection{Euclidean Distance}

Euclidean Distance is a method used to measure the distance between 2 (two) different points. This method will be used to calculate the distance of the input feature vector and the weight feature vector obtained from the extraction of texture features [14]. The following formula is used [15]. 


$$
d(p, q)=\sqrt{\sum_{i=1}^{n}\left(q_{i}-p_{i}\right)^{2}}
$$

Description:

$p, q=$ two points in Euclidean n-space

$q_{i}, p_{i}=$ Euclidean vectors, starting from the origin of the space (initial point)

$n=\mathrm{n}$-space

\subsection{Learning Vector Quantization}

Learning vector quantization (LVQ) is a pattern classification method where each output unit represents a particular category or class. The learning process in LVQ is carried out through several epochs (time span) until the maximum epoch limit has been passed. A competitive layer will automatically learn to classify input vectors. The classes obtained as a result of this competitive layer depend only on the distance between the input vectors [16]. The learning vector quantization architecture can be seen in the following figure:

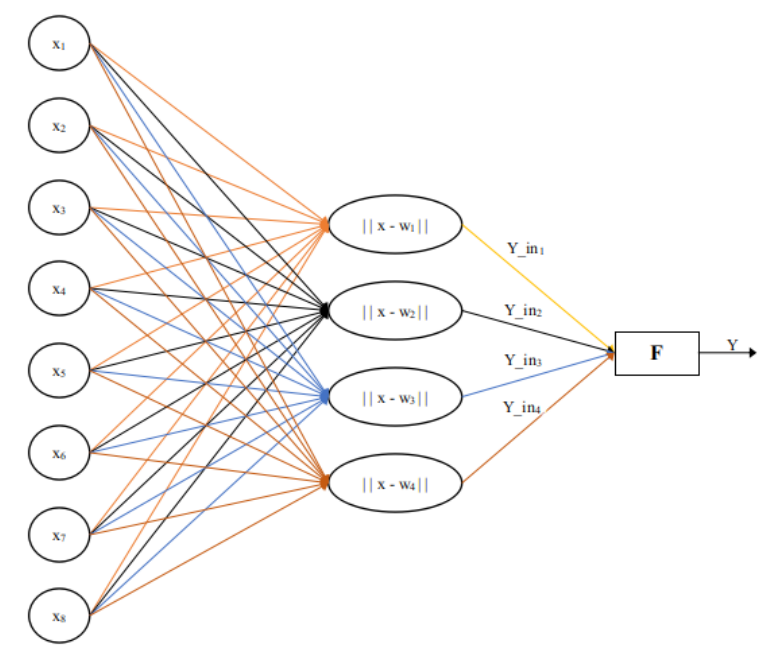

Figure 1. Learning Vector Quantization Architecture

The algorithm is as follows [17]:

1. Determine the maximum epoch (number of training processes to be repeated), eps (minimum expected error) and alpha value.

2. The results of the first feature extraction from each pattern are used as initial data (initialization). This initialization data will be filled in as the initial weight value (w).

3. Epoch $=0$.

4. As long as (Epoch $<=$ Max Epoch) and (Alpha $>=$ Eps), then do the following:

a. Epoch $=$ Epoch +1

b. For each feature extracted data, do the following:

1) Set $X=$ feature extraction result

2) Set $T=$ target of each class

3) Calculate the current feature extraction distance with each weight.

4) If the class number on the weight that has the smallest distance is the same as the target value $(\mathrm{T})$, then calculate:

5) If not, then calculate:

$$
w_{j}(\text { baru })=w_{j}(\operatorname{lama})+\alpha\left(x-w_{j}(\text { lama })\right)
$$


c. Subtract Alpha value:

$$
w_{j}(\text { baru })=w_{j}(\operatorname{lam} a)-\alpha\left(x-w_{j}(\text { lama })\right)
$$

5. Save the training results weight $(w)$.

$$
\alpha=\alpha-(0.1 * \alpha)
$$

\subsection{Confusion Matrix}

Confusion matrix is also often called error matrix. Basically, confusion matrix provides information on the comparison of classification results carried out by the system (model) with the actual classification results. The confusion matrix is in the form of matrix table that describes the performance of the classification model on a series of test data whose true value is known [18]. Look at the following figure:

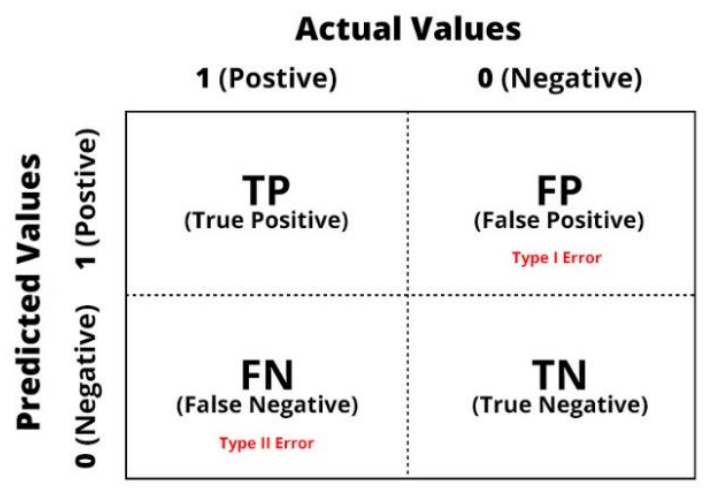

Figure 2. Confusion Matriks [18]

Confusion matrix is a matrix for measuring the performance of classification that has 4 variables, namely TP (True Positive), which means when the system predicts positive and the result is correct, TN (True Negative) when the system predicts negative and the result is correct, FP (False Positive) when the system predicts positive and the result is false, FN (False Negative) means when the system predicts negative and the result is wrong [19]. There are several calculations that can be used as tests on the system including [11].

$$
\begin{gathered}
\text { Accuracy }=\frac{(T P+T N)}{(T P+T N+F P+F N)} \\
\text { Precision }=\frac{(T P)}{(T P+F P)} \\
\text { Recall }=\frac{T P}{(T P+F N)}
\end{gathered}
$$

\section{Methodology}

\subsection{Image}

The dataset used is image data from bananas taken from their own garden, location of Pohuwato, Gorontalo. The banana used as the object of this study, namely Kepok banana, used as the study material because it is easy to obtain and often used as food ingredient by small traders. Banana image is taken using webcam camera with one photo for each side of the formaldehyde and natural bananas with light conditions during the day. The image that has been taken is then cut so that it is focused on the banana body and has resolution of $650 \times 500$. Here are the sample data in Figure 3: 

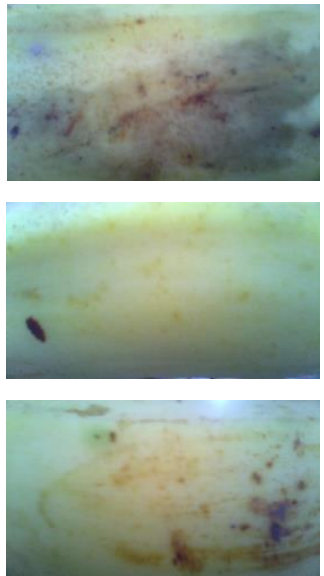

(a)
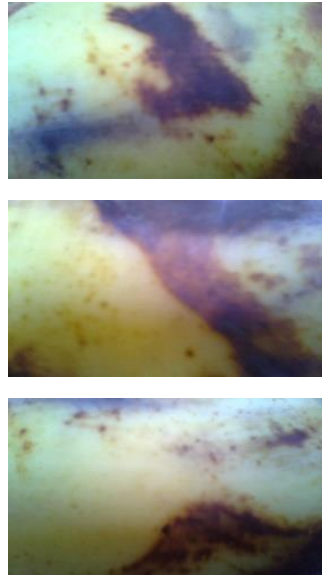

(b)

Figure 3. Sample Data (a) Natural Banana, (b) Formaldehyde Banana

\subsection{Grayscale Image}

At this stage, the RGB (Red Green Blue) image color transformation process is carried out to grayscale. This transformation is carried out so that the process is focused on one layer and calculation will be faster. The calculation process uses formula (1).

\subsection{Texture Features}

At this stage, the feature extraction process is carried out from grayscale image with texture. Extraction of texture features is carried out to take the image features, this features are very influential in the classification of data to determine formaldehyde bananas. The features used can be seen in subsection 2.2 and the results of the feature extraction are in the form of vectors, or often called as feature vectors.

\subsection{Parameter}

In this process, parameter is determined that can determine the level of accuracy of a system that has been built. The parameter used in this study is as the following Table 1 .

Table 1. Training Parameter

\begin{tabular}{ll}
\hline \multicolumn{1}{c}{ Parameter } & \multicolumn{1}{c}{ Nilai } \\
\hline Number of Training Data & 100 \\
Number of Test Data & 22 \\
Number of Targets & $2(1=$ Alami, 2 = Formalin $)$ \\
Alfa / Learning Rate & $0.1,0.01,0.001,0.0001$ \\
Dec alpha / Decrease Learning Rate & $0.05,0.1,0.25,0.5,0.75$ \\
Min alpha / Minimum Learning Rate & 0.00001 \\
Max epoch / Maximum Epoch & 1000 \\
Epoch & 0 \\
\hline
\end{tabular}

\subsection{LVQ Training}

Extraction of texture features from the previous process resulted in 7 (seven) texture data (mean, standard deviation, energy, entropy, skewness, kurtosis and smoothness) in the form of vectors as described in subsection 3.3. The vector is then used as input data in the training process using Learning Vector Quantization. The stages for training are listed in the following flowchart: 


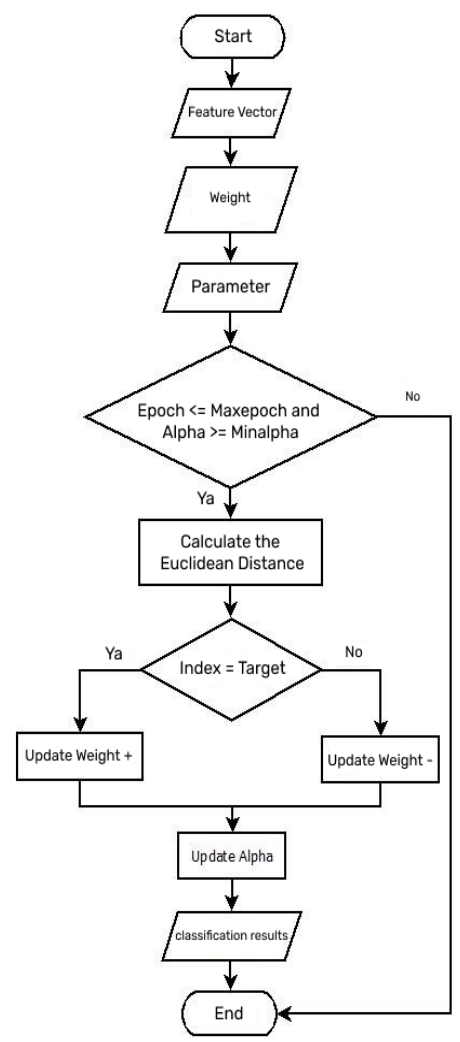

Figure 4. Learning Vector Quantization Training

The training process starts from initializing the input data. Two inputs will be initialized into the $1^{\text {st }}$ and $2^{\text {nd }}$ training weights, namely the formaldehyde banana feature data and the natural banana feature data, while the rest will be used as learning input. The next step is to determine the epoch value, learning rate (alpha), and the decrease in learning rate value (Dec alpha). After the epoch value is determined, at the $1^{\text {st }}$ epoch the shortest distance is calculated with the $1^{\text {st }}$ and $2^{\text {nd }}$ training weights. After the shortest distance on the $1^{\text {st }}$ and $2^{\text {nd }}$ weights are obtained, then the smallest distance is selected for the multiplication process with the learning rate value. The results of the calculation will be used as the new weights; the process is carried out until the value of the last learning input is obtained at the $1^{\text {st }}$ epoch. Before entering the next epoch, the learning rate (alpha) value will be updated by multiplying Dec alpha with the old learning rate. After the new learning rate value is obtained, the same calculation process as the $1^{\text {st }}$ epoch will be carried out until it reaches the specified number of epochs. The final training weight will be obtained after reaching the specified number of epochs for use in the next process.

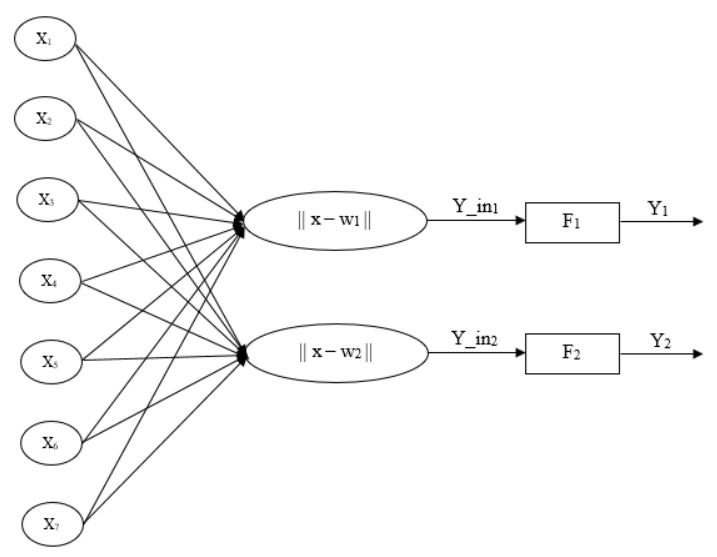

Figure 5. LVQ Architecture that Uses 


\subsection{LVQ Testing}

After the training stage with LVQ has been completed, the next process is to test the test data to match the introduction results obtained from training with testing. The final weight of the training process will be used to calculate the distance in the test data. Here in Figure 6 is the flowchart:

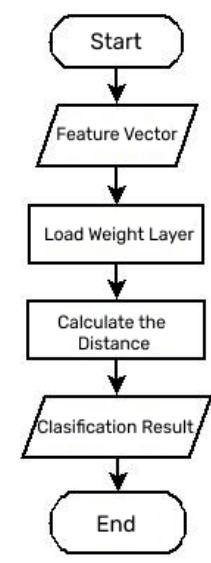

Figure 6. Learning Vector Quantization Testing

Testing is a process to see whether the classification process is correct or not. The classification results can be seen in a confusion matrix in which there is the amount of data entering the correct and the wrong classes. Then the calculation can be done to determine accuracy, precision and recall for each data class.

\subsection{Software}

The software used in this study is built using MATLAB version 2016a with several libraries that have been provided such as rgb2gray to change colors from RGB to Grayscale, xlsread to read the results of the extraction that has been done, plotconfusion to calculate the Confusion Matrix and several other libraries.

\section{Result and Discussion}

In this study, 122 digital image data of bananas are used which are divided into two classes, namely natural bananas and formaldehyde bananas, then divided into 100 images as training data consisting of 50 for natural bananas, 50 for formaldehyde bananas and 22 images for testing data. All image data goes through RGB (Red Green Blue) color transformation process to Grayscale. Here is an example:

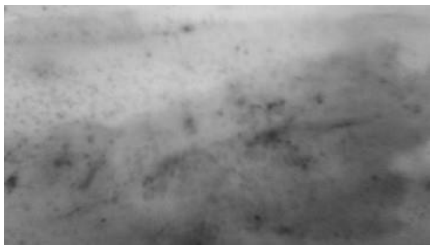

(a)

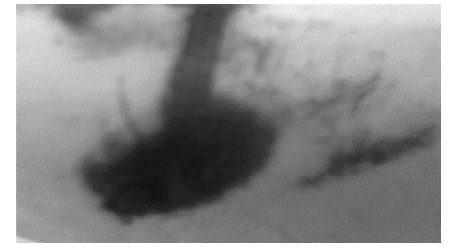

(b)

Figure 7. Sample Data Grayscale (a) Natural Banana, (b) Formaldehyde Banana

\subsection{Feature Extraction}

The next stage after converting it to Grayscale or grayscale level, then the image can be processed to obtain the mean, standard deviation, energy, entropy, skewness, kurtosis, and smoothness values. This texture feature is later used for the input value in the LVQ classification. The following is an example of the results of feature extraction: 
Table 2. Feature Extraction

\begin{tabular}{ccccccccc}
\hline No & $\begin{array}{c}\text { Training } \\
\text { Data }\end{array}$ & Average & $\begin{array}{c}\text { Standard } \\
\text { Deviation }\end{array}$ & Skewness & Kurtosis & Energy & Entropy & Smoothness \\
\hline 1 & AL01.jpg & 155,0965 & 38,19906 & $-0,23145$ & $-2,9991$ & 0,009206 & 4,810881 & 0,021948 \\
2 & AL02.jpg & 148,5776 & 43,29244 & $-0,63556$ & $-2,99832$ & 0,008138 & 4,933428 & 0,028016 \\
3 & AL03.jpg & 146,2624 & 28,92958 & $-0,0496$ & $-2,99966$ & 0,009959 & 4,682458 & 0,012707 \\
. & $\ldots$ & $\ldots$ & $\ldots$ & $\ldots$ & $\ldots$ & $\ldots$ & $\ldots$ & $\ldots$ \\
\hline 00 & FR50.jpg & 143,8043 & 57,36483 & $-0,58149$ & $-2,99521$ & 0,005624 & 5,252808 & 0,048169 \\
\hline
\end{tabular}

The following table shows the results of the LVQ (Learning Vector Quantization) classification on the training data with each of the parameters mentioned in the subsection above.

Table 3. Training Data Recognition

\begin{tabular}{clcc}
\hline $\begin{array}{c}\text { Decrease Learning } \\
\text { Rate (Dec alpha) }\end{array}$ & $\begin{array}{c}\text { Learning Rate } \\
\text { (Alpha) }\end{array}$ & Epoch & Recognition (\%) \\
\hline \multirow{3}{*}{0.05} & 0.1 & 180 & 87 \\
& 0.01 & 135 & 87 \\
& 0.001 & 90 & 88 \\
& 0.0001 & 45 & 87 \\
0.1 & 0.1 & 88 & 87 \\
& 0.01 & 66 & 87 \\
& 0.001 & 44 & 88 \\
& 0.0001 & 22 & 87 \\
0.25 & 0.1 & 33 & 89 \\
& 0.01 & 25 & 88 \\
& 0.001 & 17 & 87 \\
0.5 & 0.0001 & 9 & 87 \\
& 0.1 & 14 & 90 \\
& 0.01 & 10 & 88 \\
& 0.001 & 7 & 87 \\
0.75 & 0.0001 & 4 & 87 \\
& 0.1 & 7 & 94 \\
& 0.01 & 5 & 88 \\
& 0.001 & 4 & 87 \\
\hline
\end{tabular}

Based on the results of the performance in Table 3, the results of the accuracy of identification of the best formaldehyde bananas using parameter with Learning Rate (Alpha) $=0.1$ and decrease in Learning Rate (Dec Alpha) $=0.75$ with the smallest iteration of 7, with the highest percentage result of 94\%. The next step is to test with test data, this test is carried out to determine the closest distance between the test data and the final weight of each class. The following is the calculation of accuracy, precision and recall on the test data with each parameter.

Table 4. Accuracy, Precision and Recall Result On Test Data

\begin{tabular}{clccc}
\hline Dec Alpha & Alpha & Accuracy & Precision & Recall \\
\hline \multirow{3}{*}{0.05} & 0.1 & $81.81 \%$ & $73.33 \%$ & $100 \%$ \\
& 0.01 & $81.81 \%$ & $73.33 \%$ & $100 \%$ \\
& 0.001 & $86.36 \%$ & $78.57 \%$ & $100 \%$ \\
& 0.0001 & $86.36 \%$ & $78.57 \%$ & $100 \%$ \\
0.1 & 0.1 & $81.81 \%$ & $73.33 \%$ & $100 \%$ \\
& 0.01 & $81.81 \%$ & $73.33 \%$ & $100 \%$ \\
& 0.001 & $86.36 \%$ & $78.57 \%$ & $100 \%$ \\
0.25 & 0.0001 & $86.36 \%$ & $78.57 \%$ & $100 \%$ \\
& 0.1 & $86.36 \%$ & $78.57 \%$ & $100 \%$ \\
& 0.01 & $86.36 \%$ & $78.57 \%$ & $100 \%$ \\
& 0.001 & $86.36 \%$ & $78.57 \%$ & $100 \%$ \\
& 0.0001 & $86.36 \%$ & $78.57 \%$ & $100 \%$
\end{tabular}




\begin{tabular}{lllll} 
& 0.1 & $86.36 \%$ & $78.57 \%$ & $100 \%$ \\
& 0.01 & $86.36 \%$ & $78.57 \%$ & $100 \%$ \\
0.5 & 0.001 & $86.36 \%$ & $78.57 \%$ & $100 \%$ \\
& 0.0001 & $86.36 \%$ & $78.57 \%$ & $100 \%$ \\
& $\mathbf{0 . 1}$ & $\mathbf{9 0 . 9 0 \%}$ & $\mathbf{8 4 . 6 1 \%}$ & $\mathbf{1 0 0 \%}$ \\
& 0.01 & $86.36 \%$ & $78.57 \%$ & $100 \%$ \\
$\mathbf{0 . 7 5}$ & 0.001 & $86.36 \%$ & $78.57 \%$ & $100 \%$ \\
& 0.0001 & $86.36 \%$ & $78.57 \%$ & $100 \%$ \\
\hline
\end{tabular}
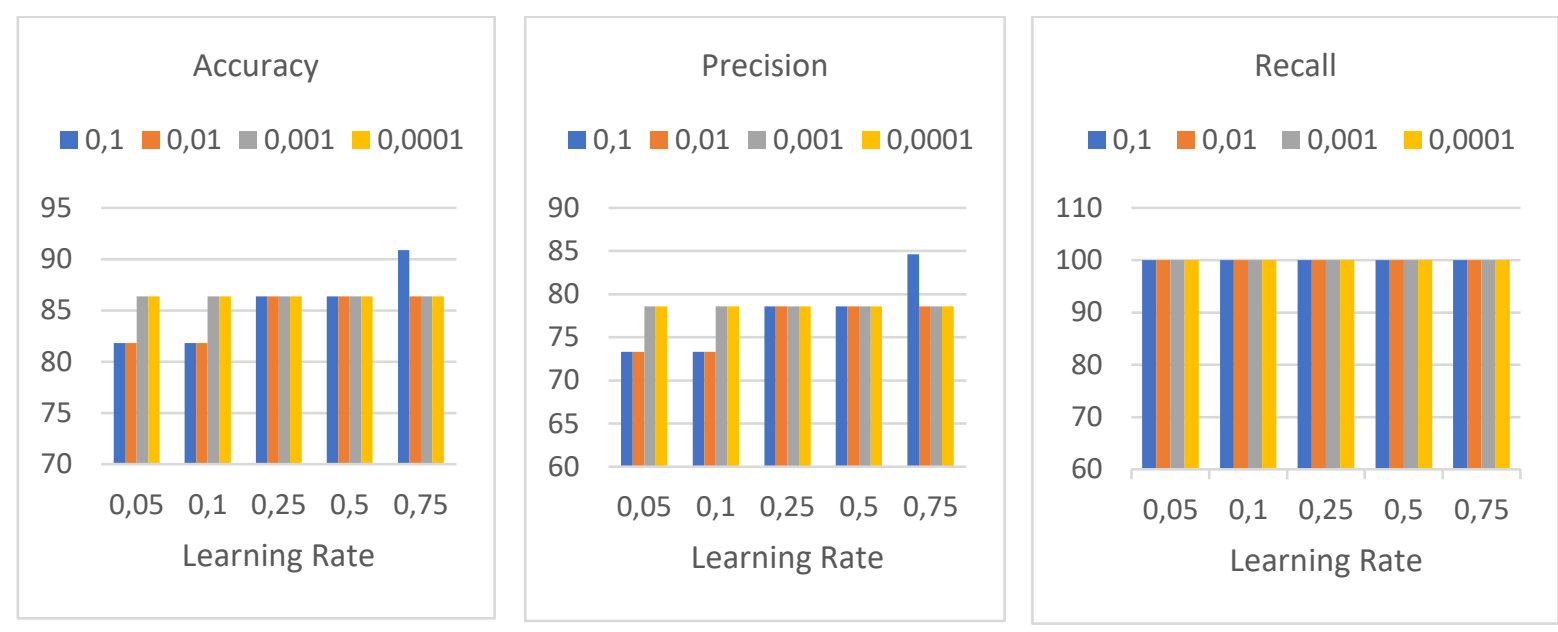

Figure 8. Confusion Matrix Result

From the test results shown above, the best accuracy is obtained at learning rate (Alpha) of 0.1, decrease in learning rate (Dec Alpha) of 0.75 with the smallest iteration of 7 obtaining the result of $90.90 \%$ accuracy, $84.61 \%$ precision and $100 \%$ recall.

\section{Conclusion}

In this article, the identification of formalin bananas using LVQ has been presented. Based on the data of study and discussion results that has been described, there are several important things that can be concluded from this study. From 122 banana images, 100 images are training data and 22 images are test data. Testing with the LVQ (Learning Vector Quantization) algorithm to identify formaldehyde bananas is able to produce $94 \%$ accuracy on training data and $90.90 \%$ accuracy, $84.61 \%$ precision, $100 \%$ recall on test data. The best parameters of training rate and decreasing of training rate are 0.1 and 0.75 , respectively.

\section{References}

[1] F. S. P. NG, "A brief history of bananas," Agriculture Utar Science Journal, vol. I, no. 1, pp. 19, 2015.

[2] B. Blandina, L. A. M. Siregar and H. Setiado, "Identifikasi Fenotipe Pisang Barangan (Musa Acuminata Linn) di Kabupaten Deli Sedang Sumatra Utara," Jurnal Agroekoteknologi FP USU, vol. 7, no. 1, pp. 94-105, 2019.

[3] R. DokterSehat, "Artikel Kesehatan," 15 November 2018. [Online]. Available: https://doktersehat.com.

[4] I. A. Sabilla, C. S. Wahyuni, C. Fatichah and D. Herumurti, "Determining Banana Types and Ripeness from Image using Machine Learning Methods," IEEE, pp. 409-410, 2019.

[5] S. F. R. Abdullah and R. Passarella, "Identifikasi Tanaman Buah Bedasarkan Fitur Bentuk, Warna, dan Tekstur Daun Bebasis Pengolahan Citra dan Learning Vector Quantization (LVQ)," 
Prosiding Annual Research Seminar 2017, Computer Science and ICT, vol. 3, no. 1, pp. 65-69, 2017.

[6] J. Waldchen and P. Mader, "Plant Species Identification Using Computer Vision Techniques: A Systematic Literature Review," Arch Computat Methods Eng, pp. 1-37, 2017.

[7] N. Bhatia and V., "Survey of Nearest Neighbor Techniques," (IJCSIS) International Journal of Computer Science and Information Security, vol. 8, no. 2, pp. 302-305, 2010.

[8] J. Du, D. Huang, X. Wang and X. Gu, "Shape Recognition Based on Radial Basis Probabilistic Neural Network and Application to Plant Species Identification," in Advanced in Neural Network , pp. 281-285, 2005.

[9] X. Zhang, F. An, L. Chen, I. Ishi and J. H. Mattausch, "A Modular and Reconfigurable Pipeline Architecture for Learning Vector Quantization," IEEE TRANSACTIONS ON CIRCUITS AND SYSTEMS-I; REGULAR PAPERS, pp. 3312 - 3325, 2018.

[10] T. S. Lim, W. Y. Loh and Y. S. Shih, "A Comparison of Prediction Accuracy, Complexity, and Training Time of Thirty-Three Old and New Classification Algorithms," Machine Learning, vol. 40, no. 3, pp. 203-228, 2000.

[11] F. S. Faisal, T. F. M. Butarbutar and P. Sirait, "Implementasi CNN dan SVM untuk Identifikasi Penyakit Tomat via Daun," Jurnal SIFO Mikroskil, p. 18, 2019.

[12] MathWorks, "Support: Documentation," 21 juli 2020. [Online]. Available: http://mathworks.com.

[13] A. Kadir and A. Susanto, "Teori dan Aplikasi Pengolahan Citra," in Teori dan Aplikasi Pengolahan Citra, Yogyakarta, CV.ANDI OFFSET (Penerbit Andi), 2013, pp. 534-535.

[14] R. Rizaldi, A. Kurniawati and C. V. Angkoso, "Implementasi Metode Euclidena Distance Untuk Rekomendasi Ukuran Pakaian Pada Aplikasi Ruang Ganti Pakaian," Jurnal Teknologi Informasi dan Ilmu Komputer (JTIIK), pp. 132-133, 2018.

[15] A. Robbinson, "How to Calculate Euclidean Distance," SCIENCING, 31 May 2013. [Online]. Available: http://www.sciencing.com. [Accessed 1712 2020].

[16] C. Husna, "Klasifikasi Penyakit Kanker Usus Besar (Colorectal) Menggunakan Algoritma Learnign Vector Quantization," Skripsi, pp. 13-15, 2018.

[17] A. P. Engelbrecht, Computational Intelligence, South Africa: WILEY, 2007.

[18] K. S. Nugroho, "Medium: Confusion Matrix untuk Evaluasi Model pada Supervised Learning," 13 November 2019. [Online]. Available: http://www.medium.com.

[19] S. Narkhede, "Understanding Confusion Matrix," 23 Juli 2018. [Online]. Available: http://towardsdatascience.com. 